\title{
EAGE
}

\section{Formation of Sinkholes in the Kinta Valley, Perak}

\author{
W.S. Chow, B.J Pierson, A.K. Askury \& Z.T.H Zuhar \\ (Universiti Teknologi PETRONAS)
}

\begin{abstract}
The first documented occurrence of sinkholes in the Kinta Valley was reported in the 1950s when a sinkhole occurred beside a railway track near Pengkalan. Since then, sinkhole occurrences were documented in the archives of the Minerals and Geoscience Department. The incidents of sinkhole occurrence reached a peak in the 1970s and 80s just before the collapse of the tin-mining industry in the Kinta valley where more than 50 sinkholes were found in the Lahat-Bukit Merah area.

Limestone is found in the Kinta Valley as karstic mogote and as bedrock overlain by stanniferous alluvium or sand tailings which are remnants from the once-flourishing tin-mining industry. About $80 \%$ of the Kinta Valley is underlain by limestone. Natural dissolution of the subsurface limestone by the slightly acidic rainwater gives rise to a karstic profile where there are steep pinnacles and deep troughs with numerous cavities and caverns. With time, the roofs over many of these subsurface cavities and caverns become thinner and ultimately, they collapse into the cavities and caverns. If the groundwater table is high, the hydrostatic pressure on the openings of the cavities or caverns upholds the collapse of the overlying soil. However, if there is a lowering of the groundwater table, there will be a rapid of collapse of the soil into the cavities or caverns leading to the formation of sinkholes.

The sinkholes in the Kinta Valley are found within a north-northeast trending zone along the western flank of the valley, stretching from Lahat in the south to Jelapang in the north over a distance of about 12 kilometres. Aerial photograph studies show that this sinkhole-prone zone is close to and almost parallel to the faulted granite-limestone contact. To the east, sinkholes had formed near Gunung Lanno in the south and in the Gunung Rapat and Gunung Panjang areas further north, falling within a north-northwest trending zone.

Once a sinkhole has been formed, it would indicate that there is a cavity or cavern within the bedrock and it is connected via a funnel or opening to the surface of the ground. The most practical solution to mitigate the problem is to plug the funnel or opening with a mixture of clay, sand and gravels to prevent further collapse of the surrounding soil.
\end{abstract}

